\title{
PENERAPAN PENDEKATAN OPEN ENDED PROBLEMS DALAM MENINGKATKAN HASIL BELAJAR MATEMATIKA SISWA KELAS V SD NEGERI 206 UJUNG BARU KABUPATEN SOPPENG
}

\author{
Awaluddin Muin \\ Prodi PGSD Fakultas Ilmu Pendidikan Universitas Negeri Makassar \\ awaluddin.muin@unm.ac.id
}

\begin{abstract}
The problems in this research is the lack of learning outcomes, especially in mathematics subject. The problem in this research is "How to applicate the open ended problems approach to improve mathematics learning outcomes in V grade 206 Ujung Baru Elementary School Districs Lilirilau, Soppeng?". The purpose of this research is to describe the implementation of open ended problems approach to improve mathematics learning outcomes in V grade 206 Ujung Baru Elementary School Districs Lilirilau, Soppeng. This research use a qualitative descriptive approach with cyclicclassroom action research that includes planning, implementation, observation, and reflection. The focus of this research is the implementation and success of the open ended problems approach in mathematic teaching and learning process and also mathematics learning outcomes of the students class $V$. Subject in this research is V grade students in 206 Ujung Baru Elementary School totaling 10 students, consist of 7 female students and 3 male students who were active in the second semester of the school year 20015/2016. Data collection techniques in this research were the test, observation, and documentation. Data analysis techniques in this research were 1) data reduction, 2) data description, and 3) and deduction. The data in this research is the activities of teacher and students, and also students learning outcomes in mathematics subject. The result of this research shows the increase of the process and outcomes of mathematics learning in each cycle. The increasing of learning process and results can be seen from the 1" cycle to 2" cycle. Learning process and result 1" cycle is including sufficient qualification and then become better qualified on the 2" cycle. The conclusions of this research is the implementation of open ended problems approach can improve mathematic learning outcomes of the students class V 206 Ujung Baru Elementary School distric Lilirilau, Soppeng.
\end{abstract}

Key Word: open ended problems approach, mathematics learning outcomes

\section{PENDAHULUAN}

Pendidikan merupakan sarana penting untuk meningkatkan kualitas sumber daya manusia dalam menjamin keberlangsungan pembangunan suatu bangsa, sehingga peningkatan kualitas sumber daya manusia jauh lebih mendesak untuk segera direalisasikan. Pendidikan merupakan sebuah proses dinamis dan berkelanjutan yang bertugas memenuhi kebutuhan guru dan siswa sesuai dengan minat mereka masing-masing karena pendidikan adalah hak semua anak, bahkan pendidikan mendapat perhatian khusus yang tercantum secara eksplisit dalam pembukaan UUD 1945 pada alenia keempat.

Zaman globalisasi sekarang ini diperlukan sumber daya manusia yang handal dan mampu berkompetisi secara global, sehingga siswa dituntut untuk lebih kreatif, berpikir logis, konsisten, dapat bekerjasama, mengembangkan ide, berpikir kritis serta tidak cepat putus asa. Salah satu mata pelajaran yang merefleksikan sifat di atas adalah mata pelajaran matematika, karena matematika merupakan ilmu dasar dan hampir melayani setiap ilmu, sehingga ada ungkapan bahwa matematika itu adalah ratu dan pelayan ilmu (Karsodkk, 2008).

Matematika merupakan ilmu yang sangat erat kaitannya dengan kehidupan sehari-hari dan dipelajari oleh siswa sejak dini. "Matematika adalah bahasa simbol tentang berbagai gagasan dengan menggunakan istilahistilah yang didefenisikan secara cermat, jelas, dan akurat" (Runtukahu dan Kandou, 2014 : 28). Matematika berfungsi untuk mengembangkan kemampuan berkomunikasi dengan menggunakan bilangan dan simbolsimbol serta ketajaman penalaran yang dapat membantu memperjelas dan menyelesaikan 
permasalahan dalam kehidupan sehari-hari. Fungsi matematika yang dijadikan acuan dalam pembelajaran matematika sekolah dasar adalah matematika sebagai alat, pola pikir, dan ilmu atau pengetahuan (Erman, 2003).

Tujuan matematika khususnya di Sekolah Dasar (SD) atau Madrasah Ibtidiyah (MI) yaitu agar siswa memiliki kemampuan sebagai berikut :

1)Memahami konsep matematika, menjelaskan keterkaitan antarkonsep dan mengaplikasikan konsep atau alogaritma, secara luwes, akurat, efisien, dan tepat, dalam pemecahan masalah; 2) Menggunakan penalaran pada pola dan sifat, melakukan manipulasi matematika dalam membuat generalisasi, menyusun bukti, atau menjelaskan gagasan dan pernyataan matematika; 3) Memecahkan masalah yang meliputi kemampuan memahami masalah, merancang model matematika, menyelesaikan model dan menafsirkan solusi yang diperoleh; 4) Mengkomunikasikan gagasan dengan simbol, tabel, diagram, atau media lain untuk memperjelas keadaan atau masalah; 5) Memiliki sikap menghargai kegunaan matematika dalam kehidupan, yaitu memiliki rasa ingin tahu, perhatian, dan minat dalam mempelajari matematika, serta sikap ulet dan percaya diri dalam pemecahan masalah (Aisyah dkk, 2007 : $1-4)$.

Tujuan matematika di atas diharapkan dapat dicapai oleh siswa secara maksimal. Oleh karena itu, guru sebagai fasilitator dan motivator harus merancang pembelajaran khusus untuk menjadikan matematika sebagai mata pelajaran yang diminati oleh siswa melalui pendekatan pembelajaran yang sesuai dengan karakteristik siswa. Mengingat adanya perbedaan karakteristik diantara sesama siswa maka diperlukan kemampuan khusus dari guru untuk menjembatani antara dunia siswa yang belum berpikir deduktif agar dapat mengerti dunia matematika yang bersifat deduktif, sehingga siswa dapat merasa bersahabat dengan matematika (Karso dkk, 2008).
Matematika diharapkan dapat membekali siswa dengan kemampuan berpikir logis, sistematis, kritis dan kreatif serta memiliki kemampuan kerja sama untuk meningkatkan keefektifan pembelajaran, sehingga hasil belajar yang diperoleh sesuai dengan tujuan yang akan dicapai. Oleh karena itu, diharapkan bahwa matematika sebagai ilmu dasar perlu dikuasai dengan baik oleh siswa terutama sejak usia sekolah dasar karena dibutuhkan dalam dunia kerja dan untuk mendukung perkembangan ilmu pengetahuan.

Namun pada kenyataannya, penguasaan matematika di sekolah dasar masih tergolong kurang dan jauh dari harapan sehingga menjadi permasalahan yang krusial. Berdasarkan pra penelitian yang telah dilakukan oleh peneliti selama dua minggu yaitu dimulai pada tanggal 9November hingga 17 November 2015 dengan mengggunakan teknik observasi pada pembelajaran matematika di kelas V SD Negeri 206 Ujung Baru Kecamatan Lilirilau Kabupaten Soppeng menunjukkan adanya permasalahan dalam pembelajaran matematika di lapangan. Hasil observasi menunjukkan bahwa rendahnya hasil belajar matematika dipengaruhi oleh faktor dari guru dan siswa sebagai berikut: 1) penerapan metode pembelajaran matematika yang masih terpusat pada guru (techer oriented), sehingga siswatidak leluasa mengembangkan kemampuan bernalarnya dan kurang tertarik mengikuti pembelajaran matematika, 2) metode yang digunakan guru kurang bervariasi yaitu setelah menjelaskan siswa hanya langsung diberi tugas latihan sehingga motivasi siswa sulit ditumbuhkan dan cepat merasa jenuh, 3) guru kurang memfasilitasi siswa dalam berkelompok sehingga banyak siswa yang tidak ikut berpartisipasi bahkan hanya mengandalkan hasil kerja temannya, 4) guru kurang memberikan berbagai contoh bentuk soal yang bervariasi sehingga mengakibatkan rendahnya kemampuan berpikir kritis dan kreatif yang dilihat dari kurangnya pemahaman siswa dalam menjawab soal-soal yang diberikan. Jika siswa diberikan soal latihan yang berbeda dengan contoh yang diberikan, mereka mengalami kesulitan.

Selain faktor dari guru dan siswa, kondisi sekolah di SD Negeri 206 Ujung Baru Kecamatan Lilirilau Kabupaten Soppeng juga merupakan faktor eksternal yang menyebabkan rendahnya hasil belajar matematika siswa kelas V. Kondisi sekolah yang masih minim dengan fasilitas sepertibuku-buku pelajaran sehingga 
dalam mengajar, guru kelas hanya terpaku pada satu buku matematika. Kondisi bangunan kelas yang ada di sekolah tersebut juga turut menjadi pemicu rendahnya hasil belajar siswa karena terdapat keretakan yang cukup parah pada bagian dinding maupun lantai kelas sehingga pada saat pembelajaran berlangsung seringkali guru maupun siswa merasa ketakutan karena dapat mengancam keselamatan mereka, sehingga mengakibatkan terganggunya konsentrasi siswa dalam belajar.

Peneliti melanjutkan pra penelitian pada tanggal 23 November 2015 di SD Negeri 206 Ujung Baru Kecamatan Lilirilau Kabupaten Soppeng tentang hasil belajar siswa kelas V dengan menggunakan dokumentasi. Peneliti mendapatkan data dokumentasi nilai siswa dari guru kelas yang menunjukkan bahwa nilai rata-rata terendah dari kelima mata pelajaran pokok adalah matematika. Berdasarkan data tersebut menunjukkan bahwa nilai rata-rata ulangan harian dan hasil ulangan tengah semester matematika siswa kelas V yaitu hanya mencapai 64 dari 10 jumlah siswa.Hanya 3 siswa dengan persentase $30 \%$ yang mencapai nilai KKM yang telah ditentukan yaitu 71 dan 7siswa dengan persentase $70 \%$ yang memperoleh nilai di bawah KKM.

Masalah tersebut harus segera diatasi karena akan berdampak buruk bagi siswa khususnya pada peningkatan hasil belajar dan perkembangan kognitif, afektif, psikomotor dan kreatifitas siswa. Salah satu usaha yang dianggap dapat mengatasi masalah tersebut adalah pemberian pendekatan pembelajaran yang tepat sasaran oleh guru. Oleh karena itu, peneliti menerapkan pendekatanopen ended problems dalam pembelajaran matematika.Pemilihan pendekatan open endedproblems dalam penelitian ini didasarkan atas hasil penelitian Setiamihardja dan Kusmiyati yang telah mengadakan penelitian menggunakan pendekatan tersebut sebelumnya pada tahun 2007 yang lalu di SDN Bojongsempur, Kecamatan Cikancung Kabupaten Bandung. Hasil penelitian menunjukkan adanya prestasi siswa yang mencapai rata-rata 9,04 atau sekitar 90,4\%. Tingkat pencapaian tersebut sudah termasuk kualifikasi baik pada mata pelajaran matematika.

Pendekatanopen ended problems merupakan proses pembelajaran yang di dalam tujuannya dan keinginan individu dibangun dan dicapai secara terbuka (Huda,
2013).Pembelajaran terbuka artinya pembelajaran dimulai dengan memberikan masalah terbuka kepada siswa, selanjutnya mereka diminta untuk mengembangkan metode atau cara yang berbeda sesuai dengan kemampuan dan pengetahuan yang telah mereka miliki sebelumnya dalam upaya memperolah jawaban yang benar (Shoimin, 2014).Oleh karena itu, pendekatan open endedproblems diharapkan mampu mengembangkan kreativitas serta pola pikir matematis siswa melalui pemecahan masalah dan mampu membantu siswa dalam meningkatkan hasil belajar matematika.

Adapun menurut Shoimin, 2014 langkahlangkah pendekatan open ended problems terdiri dari tahap persiapan, tahap pelaksanaan yang meliputi pendahuluan, kegiatan inti dan kegiatan akhir serta tahap evaluasi. Berikut akan dibahas secara rinci :

1) Persiapan

Sebelum memulai proses belajar mengajar, guru harus membuat program satuan pelajaran yaitu rencana pelaksanaan pembelajaran (RPP) dan membuat pertanyaan atau soal open ended problems yang dituangkan di dalam Lembar Kerja Siswa (LKS) serta segala sesuatu yang dibutuhkan dalam proses pembelajaran.

2) Pelaksanaan, terdiri dari :

a) Pendahuluan

Siswa menyimak motivasi yang diberikan oleh guru bahwa yang akan dipelajari berkaitan dengan kehidupan seharihari sehingga mereka semangat dalam belajar. Siswa kemudian menanggapi apersepsi yang diberikan oleh guru untuk mengetahui kemamapuan awal mereka.

b) Kegiatan inti

Yaitu pelaksanaan pembelajaran dengan mengikuti langkah-langkah berikut :

(1) Siswa membentuk kelompok yang terdiri dari lima orang.

(2) Siswa mendapatkan pertanyaan open ended problems.

(3) Siswa berdiskusi bersama kelompok mereka masing-masing mengenai penyelesaian dari pertanyaan open ended problems yang telah diberikan oleh guru.

(4) Setiap kelompok melalui perwakilannya, mengemukakan pendapat atau solusi yang ditawarkan kelompoknya secara bergantian.

(5) Siswa atau kelompok kemudian menganalisis jawaban-jawaban yang telah 
dikemukakan, mana yang benar dan mana yang lebih efektif.

c) Kegiatan akhir

Siswa menyimpulkan apa yang telah dipelajari, kemudian kesimpulan tersebut disempurnakan oleh guru.

\section{3) Evaluasi}

Setelah berakhirnya kegiatan belajar mengajar, siswa diberikan tugas perorangan atau ulangan harian yang merupakan evaluasi yang berisi pertanyaan open ended problems. Oleh karena itu, guru hendaknya dapat memahami dan menganalisis bagaimana cara menyajikan pembelajaran yang bermakna yang sesuai kebutuhan siswa dan memberikan kepercayaan kepada siswa untuk lebih mengembangkan potensinya.

Kelebihan pendekatan open ended problems adalah menekankan pada partisipasi siswa secara aktif dalam pembelajaran sehingga siswa sering mengekspresikan idenya. Selain itu siswa dengan kemampuan rendah dapat merespon permasalahan dengan cara mereka sendiri, serta lebih mementingkan proses daripada hasil (Shoimin, 2014). Berdasarkan dari beberapa kelebihan tersebut, peneliti beranggapan bahwa pendekatan open ended problems dapat diterapkan dalam proses pembelajaran matematika karena pendekatan ini menjajikan suatu kesempatan kepada siswa untuk menginsvetigasi berbagai strategi dan cara yang dihadapi sesuai dengan kemampuan mengelaborasi permasalahan sehingga diharapkan dapat meningkatkan hasil belajar matematika siswa kelas V di SD Negeri 206 Ujung Baru Kecamatan Lilirilau Kabupaten Soppeng.

\section{METODE PENELITIAN}

Jenis penelitian ini menggunakan jenis penelitian tindakan kelas (PTK). penelitian tindakan kelas ditujukan untuk menemukan pemecahan masalah yang dihadapi guru di kelas dengan tujuan untuk meningkatkan hasil belajar siswa. Setting dalam penelitian ini meliputi : tempat dan waktu penelitian. Tempat penelitian : penelitian ini dilaksanakan di kelas V SD Negeri 206 Ujung Baru yang beralamat di Jalan Poros Bone-Soppeng Desa Parenring Kecamatan Lilirilau Kabupaten Soppeng pada semester genap tahun pelajaran 2015/2016.Subjek penelitian ini adalah guru kelas V SD Negeri 206 Ujung Baru, siswa kelas $\mathrm{V}$ yang berjumlah 10 orang siswa yang terdiri dari 3 orang siswa laki - laki dan 7 orang siswa perempuan.

Penelitian ini menggunakan pendekatan kualitatif yaitu penelitian yang dilakukan pada kondisi yang alamiah dan instrumennya adalah orang atau peneliti itu sendiri.Untuk mengumpulkan data dalam penelitian ini dilakukan dengan mengambil tes, observasi, dan dokumentasi (Sukardi, 2003). Teknik tersebut diuraikan sebagai berikut :

\section{a. Tes}

Tes merupakan teknik pengumpulan data untuk mengukur kemampuan siswa dalam aspek kognitif. Tes digunakan untuk mengetahui sejauh mana kemampuan siswa dalam menjawab pertanyaan dari tes hasil belajar pada setiap akhir siklus. Jenis tes yang digunakan adalah tes tertulis.

\section{b. Observasi}

Observasi dilakukan untuk memantau kondisi atau fakta alami, tingkah laku dan hasil kerja siswa dalam situasi alami dalam hal ini perilaku belajar siswa selama proses pembelajaran berlangsung dan perilaku peneliti itu sendiri ketika melakukan tindakan pembelajaran terhadap siswa. Dalam kegiatan observasi, peneliti lebih banyak menggunakan salah satu dari panca inderanya yaitu, indera penglihatan. Untuk memaksimalkan observasi peneliti menggunakan alat bantu misalnya buku catatan atau check list.

\section{c. Dokumentasi}

Dokumentasi yaitu memungkinkan peneliti memperoleh informasi dari sumber tertulis dari siswa yaitu nilai-nilai siswa yang telah ada.

Adapun gambaran umum mengenai rancangan Siklus Penelitian yaitu sebagai berikut :

\section{Perencanaan}

Pada setiap siklus disusun perencanaan pembelajaran untuk perbaikan pembelajaran. Perencanaan bukan hanya berisi tentang tujuan atau kompetensi yang harus dicapai melainkan harus lebih ditonjolkan perlakuan khusus guru dalam proses pembelajaran. Membuat lembar observasi guru dan siswa untuk mengamati dan mengetahui kondisi belajar mengajar di kelas pada saat berlangsungnya proses pembelajaran selama tindakan Siklus I maupun II.

\section{Melaksanakan Tindakan}

Pelaksanaan tindakan adalah perlakuan yang dilaksanakan berdasarkan perencanaan yang telah disusun. Kegiatan yang dilaksanakan pada tahap ini adalah 
melaksanakan pembelajaran dengan menyajikan materi ajar sesuai skenario pembelajaran yang telah disusun yaitu tentang operasi hitung pecahan. Dalam skenario pembelajaran harus menonjolkan tindakan yang ingin diterapkan yaitu pendekatan open ended problems dan keaktifan siswa selama proses pembelajaran berlangsung.

\section{Observasi}

Observasi

dilakukan untuk mengumpulkan informasi tentang proses pembelajaran yang dilakukan peneliti sesuai dengan tindakan yang telah disusun. Melalui pengumpulan informasi berupa pengamatan, observer dapat mencatat berbagai kelemahan dan kelebihan yang dilakukan guru dan siswa dalam melaksanakan tindakan dengan menggunakan lembar observasi yang telah disiapkan.

\section{Refleksi}

Refleksi adalah aktivitas melihat berbagai kekurangan yang dilaksanakan guru atau peneliti selama tindakan. Refleksi dimaksudkan untuk mengkaji secara menyeluruh tindakan yang telah dilakukan berdasarkan data yang terkumpul dan sebagai bahan pertimbangan apakah kriteria yang telah ditetapkan tercapai atau belum. Hasil refleksi dapat menunjukkan berbagai kekurangan yang perlu diperbaiki, sehingga dapat dijadikan dasar dalam penyusunan menuju siklus berikutnya.

\section{HASIL \& PEMBAHASAN}

\section{Paparan Data}

Jenis penelitian ini adalah Penelitian Tindakan Kelas. Hal ini dipicu oleh munculnya kesadaran pada diri guru bahwa praktik mengajar yang dilakukan di kelas selama ini mempunyai masalah yang perlu diselesaikan. Salah satu usaha untuk menyelesaikan permasalahan matematika di kelas adalah dengan menerapkan pendekatan open ended problems. Pendekatan open ended problems tersebut sengaja dipilih dengan alasanbahwa pendekatan open ended problemsmelatih dan menumbuhkan ide, kreativitas, kognitif tinggi, kritis, komunikasi-interaksi, sharing, keterbukaan, dan sosialisasi.

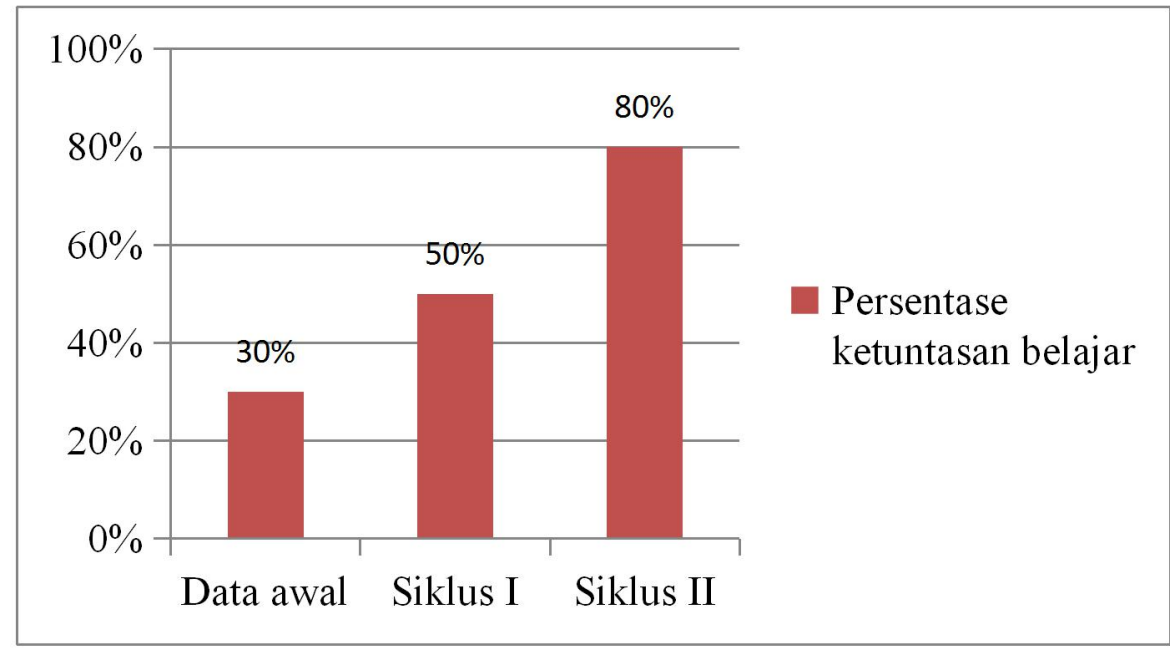

Grafik 4.1 Rekapitulasi Persentase Ketuntasan Belajar Siswa

Sebelum melaksanakan kegiatan pembelajaran dalam penelitian ini, peneliti meminta data dokumentasi di kelas V SDN 206 Ujung Baruserta melakukan observasi lebih lanjut sehingga peneliti memperoleh data awal berupa daftar nilai rata-rata dari ulangan harian dan UTS pada pembelajaran matematikahanya mencapai 64dengan persentase ketuntatasan belajar 30\%. Data awal tersebut memberikan informasi bahwa hasil belajar siswa dalam memahami materi pelajaran matematika masih tergolong dalam kualifikasi kurang.Berdasarkan kenyataan tersebut, peneliti menyusun rancangan pembelajaran yang dapat membantu siswa memahami mata pelajaran matematika dengan sampel materi yaitu operasi hitung pecahandengan menerapkan pendekatan open ended problems.

Hasil penelitian yang diperoleh pada pembelajaran siklus I pertemuan I dan pertemuan II yaitu masih terdapat banyak kekurangan sehingga hasil siklus I belum mencapai hasil yang diharapkan. Nilai rata-rata 
hasil belajar siswapada siklus I yaitu 74,3 dengan persentase ketuntasan $50 \%$ dan masih tergolong kategori cukup. Persentase ketuntasan siswa pada siklus I mengalami peningkatan $20 \%$ dari data awal. Meskipun demikian, hasil tersebut belum mencapai indikator keberhasilan yang ditetapkan oleh sekolah yaitu $75 \%$ dari seluruh jumlah siswa mendapatkan nilai $\geq 71$. Melihat kekurangankekurangan tersebut maka peneliti melanjutkan penelitian pada tindakan siklus II. Tindakan siklus II ditemukan bahwa kegiatan yang tercakup dalam pendekatan open ended problems telah berhasil terlaksana dengan baik. Hasil evaluasi siklus II menunjukkan persentase ketuntasan siswa sebesar $80 \%$ dengan nilai rata-rata 77,9 sehingga dianggap telah mencapai indikator keberhasilan.

Keberhasilan tindakan dari siklus I ke siklus II dikarenakan guru dan siswa dapat melaksanakan rancangan pembelajaran sesuai dengan langkah-langkah pendekatan open ended problems yang diterapkan, karena perlu diketahui bahwa proses pembelajaran matematika bukan sekedar transfer ilmu dari guru kepada siswa melainkan proses interaksi antara guru dan siswa (Susanto,2013). Peningkatan hasil belajar matematika yang dicapai siswa juga disebabkan karena siswa menunjukkan perubahan kebiasaan belajar yang baik di kelas. Seperti halnya yang dikemukakan oleh Anitah (2007) bahwa hasil belajar yang terjadi adalah perubahanperubahan perilaku siswa baik aspek pengetahuan, sikap maupun keterampilannya. Hasil-hasil pembelajaran matematika nampak pada kemampuan berpikir yang matematis dalam diri siswa yang bermuara pada kemampuan menggunakan matematika sebagai bahasa dan alat dalam menyelesaikan masalah yang dihadapi dalam kehidupannya (Aisyah dkk, 2007)

Tujuan pembelajaran yang telah ditetapkan telah tercapai dengan baik dan pemahaman siswa yang meningkat dalam matematika dengan sampel materi operasi hitung pecahan mengindikasikan bahwa pendekatan open ended problems dapat dijadikan sebagai salah satu pendekatan pembelajaran dalam meningkatkan hasil belajar matematika siswa di SD.

\section{KESIMPULAN \& SARAN}

Berdasarkan rumusan masalah, hasil analisis data, dan pembahasan, maka hasil penelitian ini dapat disimpulkan bahwa penerapan pendekatan open ended problems dapat meningkatkan hasil belajar matematika siswa kelas V SD Negeri 206 Ujung Baru Kecamatan Lilirilau Kabupaten Soppeng. Hal tersebut dapat dilihat dari hasil belajar siswa yang mengalami peningkatan pada setiap siklus. Jika dibandingkan dengan kemampuan siswa pada siklus I berada pada kualifikasi cukup (C), pada siklus II meningkat menjadi kualifikasi baik (B). Peningkatan hasil belajar siswa diperoleh dari proses pembelajaran aktif yang diterapkan oleh guru dengan membebaskan siswa untuk menyelesaikan persoalan matematika dengan beragam cara sehingga siswa dapat mengembangkan kreativitas, ide, penalaran dan daya analisis dan sikap kritis mereka sesuai dengan kemampuan masing-masing tanpa menghambat cara berpikirnya

Berdasarkan kesimpulan yang telah diuraikan, dikemukakan beberapa saran sebagai berikut:

1. Bagi guru diharapkan menerapkan pendekatan open ended problemsdalam proses pembelajaran untuk meningkatkan prestasi belajar siswa, tidak hanya dalam mata pelajaran matematika, tetapi juga pada mata pelajaran lain.

2. Bagi pengamat pendidikan sekolah diharapkan dapat menjadi bahan masukan, rujukan dan referensi yang dapat dijadikan acuan dalam pelaksanaan pembelajaran khususnya pada mata pelajaran matematika sehingga dapat menunjang tercapainya target kurikulum dan daya serap siswa sesuai yang diharapkan.

Bagi peneliti disarankan agar melakukan penelitian dengan menerapkan macam macam model pembelajaran yang lebih inovatif. Hal ini disebabkan karena salah satu tujuan dalam pembelajaran adalah menciptakan situasi belajar siswa menjadi lebih nyaman dan memberikan pembelajaran yang berkesan, bermakna, menarik dan menyenangkan bagi siswa serta memanfaatkan potensi yang pada dasarnya telah dimiliki siswa dengan melatih dan mengembangkannya.

DAFTAR PUSTAKA

Ahmadi, Abu.\&Prasetyo, Tri. 1997. Strategi Belajar Mengajar. Bandung :Pustaka Setia.

Aisyah, Nyimas, dkk. 2007. Bahan Ajar Cetak: Pengembangan

Pembelajaran 
Matematika SD. Jakarta : Direktorat Jenderal Pendidikan Tinggi Depdiknas.

Anitah, Sri, dkk. 2007. Strategi Pembelajaran di SD. Jakarta : UniversitasTerbuka.

Anggoro, Toha, dkk. 2008. Metodologi Penelitian. Jakarta: Universitas Terbuka.

Arikunto, Suharsimi, dkk. 2011. Penelitian Tindakan Kelas. Jakarta: Bumi Aksara. \& Abdul Jabar, Cepi. 2009. Evaluasi program Pendidikan. Jakarta: Bumi Aksara.

Erman, Suherman. Dkk. 2003. Strategi Pembelajaran Matematika Kontemporer. Bandung : UPI.

Huda, Miftahul. 2013. Model-Model Pengajaran dan Pembelajaran. Yogyakarta: Pustaka Belajar

Iskandarwassid. \& Sunendar, Dadang. 2011. Strategi Pembelajaran Bahasa. Bandung : PT. Rosda Karya.

Karso, dkk. 2008. Pendidikan Matematika 1. Jakarta: Universitas Terbuka.

Depdiknas. 2006. Kurikulum Tingkat Satuan Pendidikan (KTSP). Jakarta: Depdiknas.

Ollerton, Mike. 2010. Panduan Guru Mengajar Matematika. Diterjemahkan oleh Bob Sabran. Jakarta : Penerbit Erlangga.

Runtukahu, Tomboka. \& Kandou, Selpius. 2014. Pembelajaran Matematika Dasar Bagi Anak Berkesulitan Belajar. Yogyakarta : Ar-Ruzz Media.

Sanjaya, Wina. 2009. Penelitian Tindakan Kelas. Bandung: Kencana Prenada Media Grup.

Setiamihardja, Realin \& Kusmiyati. 2007. Pendekatan Open Ended dalam Pembelajaran Matematika di Sekolah Dasar. Jurnal Pendidikan Dasar, Nomor : 8 - Oktober 2007.

Shoimin, Aris, 2014. 68 Model Pembelajaran Inovatif dalam Kurikulum 2013. Yogyakarta : Ar-Ruzz Media.

Sinring, Abdullah, dkk. 2012. Panduan Penulisan Skripsi. Makassar: Universitas Negeri Makassar.

Soenarjo, RJ. 2008. Matematika 5 SD dan MI Kelas 5. Jakarta : Pusat Perbukuan, Departemen Pendidikan Nasional.

Sugiyono. 2012. Metode Penelitian Pendidikan. Bandung: Alfabeta

Sukardi, 2011. Metodologi Penelitian Pendidikan. Yogyakarta: Bumi Aksara.
Suma, Ketut, dkk. 2007. Pengembangan Keterampilan Berpikir Divergen Melalui Pemecahan Masalah Matematika-Sains Terpadu Open-Ended Argumentatif. Jurnal Pendidikan dan Pengajaran Undiksa, Nomor : 4 TH XXXX Oktober 2007.

Susanto, Ahmad. 2013. Teori Belajar dan Pembelajaran di Sekolah Dasar. Jakarta : PT. Kharisma Putra Utama.

Suwardi, dkk. 2002. Rumus Berhitung. Klaten : Penerbit Tunas Abadi.

Syawahid. M. 2011. Analisis Open Ended Approach dan Open Ended Question (Online),

http://wahidkkt.blogspot.com(diakses pada tanggal 12 November 2015).

Tim Bina Karya Guru. 2012. Matematika untuk Sekolah Dasar/Madrasah Ibtidaiyah Kelas V. Sidoarjo : Masmedia.

Wardhani, Igak \& Wihardit, Kuswaya. 2008. Penelitian Tindakan Kelas. Jakarta: Universitas Terbuka.

Tampubolon, Saur M. 2014. Penelitian Tindakan Kelas sebagai Pengembangan Profesi Pendidik dan Keilmuan. Jakarta : Penerbit Erlangga.

Yusmarni. 2009. Metode Pembelajaran Pendekatan Open-Ended dalam Diklat Matematika (Online), (diakses pada tanggal 17 Mei 2016). 